Sandra Soče Kraljević* Kristian Božić **
JEL Classification M30, M31, M39

Izvorni znanstveni rad

https://doi.org/10.32910/ep.70.3.6

\title{
ISTRAŽIVANJE PREFERENCIJA POTROŠAČA PRI ODABIRU TRGOVAČKIH LANACA
}

U Europskoj uniji tržištem hranom dominiraju veliki trgovački lanci, a posljednjih nekoliko godina taj trend primjetan je i u Bosni i Hercegovini. Iako su zakoni o zabrani monopola na snazi, još uvijek nema mehanizama koji mogu kontrolirati moć velikih trgovačkih lanaca. Prema istraživanju britanske Komisije za konkurenciju, svaki trgovački lanac koji ima više od osam posto udjela na tržištu hranom ima i dovoljno moći da negativno utječe na konkurentnost na tržištu te samim time i na plasman hrane.Kupovne navike potrošača jedan su od ključnih čimbenika koji utječu na sliku maloprodajnog tržišta kako na lokalnom tako i na globalnom nivou. Iako su suvremeni potrošači suvereni, itekako se može na njih marketinški utjecati. Marketari mogu utjecati na njihovo ponašanje tako što će elemente marketinškog spleta prilagoditi potrošačevim potrebama. Uspjeh se postiže ako potrebe postoje ili su latentne i proizvođač ih potakne proizvodom koji potrošači svjesno ili podsvjesno trebaju. Ponašanje potrošača je pod utjecajem brojnih čimbenika koji su međusobno povezani, a mogu se svrstati u tri skupine: osobni čimbenici, društveni čimbenici i psihološki čimbenici. Stoga, glavni cilj ovog rada je ispitati preferencije potrošača u odabiru trgovačkih lanaca na području grada Mostara. Kroz anketiranje koje će biti provedeno s potrošačima na području grada Mostara, uz njihove preferencije u odabiru trgovačkih lana-

* Dr. sc. S. Soče Kraljević, izvanredni profesor, Ekonomski fakultet, Sveučilište u Mostaru, Bosna i Hercegovina (E-mail: sandra.soce-kraljevic@sve-mo.ba, sandra.socekraljevic@yahoo.com).

${ }^{* *}$ K. Božić, mr. oec. (E-mail: kristianbozic@yahoo.com).

Rad je primljen u uredništvo 20.12.2018. godine, a prihvaćen je za objavu 21.03.2019. godine. 
ca, ispitat će se i glavne odrednice koje utječu na potrošačev odabir.Ovim radom je prezentirano primarno istraživanje koje upućuje da se razlikuju preferencije potrošača kad abiraju trgovački centar te da najrađe posjećuju najbliži trgovački centar. Značaj ili znanstveni doprinos ovog istraživanja je dvojak, ovaj rad može koristiti marketarima i menadžerima u poduzećima $i$ trgovačkim centrima koji posluju na tržištima gdje je sve veća konkurencija kako bi svoje potrošače potakli da više kupuju te time povećali prodaju $i$ konkurentnost što je podjednako važno i za znanstvenike (istraživanje tržišta, prodaja, ponašanje potrošača) s aspekta boljeg razumijevanja preferencija $i$ čimbenika koji utječu na izbor trgovačkog lanca. Na kraju rada navode se ograničenja istraživanja kao i smjernice za buduća istraživanja.

Ključne riječi: istraživanje tržišta, trgovački lanac, ponašanje i preferencije potrošača, Mostar

\section{Uvod}

Trgovina je ekonomska razmjena proizvoda, robe i pružanja usluga između dvije ili više osoba s ciljem zadovoljavanja potreba s jedne strane i ostvarivanjem prihoda s druge strane. ${ }^{1}$ Trgovina je bila prisutna i u starom vijeku. Povijesno gledajući, maloprodaja je podrazumijevala varijacije u rasponu od malih lokalnih prodavaonica pa sve do velikih trgovačkih lanaca. U prošlosti su maloprodaje bile specijalizirane za prodaju određene vrste proizvoda koje su nudile na tržištu, a povećanjem broja takvih maloprodavaonica povećala se i konkurentnost te su se eventualno, s ciljem ostvarivanja konkurentske prednosti, počele na tržištu pojavljivati i prve maloprodaje sa širokim asortimanom proizvoda. Stoga, možemo reći da je konkurentnost djelovala kao "okidač” za pokretanje maloprodaja sa širokim asortimanom proizvoda.

Danas, u mnogim dijelovima svijeta tržištem hranom dominiraju veliki trgovački lanci. Trgovački lanac je lanac trgovina koji dijele isto ime i centralnu upravu te uglavnom imaju standardiziranu poslovnu praksu. ${ }^{2}$ Jedan od ključnih čimbenika koji utječe na sliku trgovačkog lanca su kupovne navike potrošača te je jako bitno analizirati njihove navike odnosno ponašanje.

Ključne promjene u trgovini koje su se dogodile su: integriranost trgovine, promjena s lokalne na globalnu trgovinu, inovacije $\mathrm{u}$ formatima trgovina te pro-

1 Dunković, D., Poslovno upravljanje u trgovini, Ekonomski fakultet u Zagrebu, 2015., str. $2-3$.

2 www.wikipedia.hr 
storna neograničenost, trgovina sa sustavnim vođenjem, razvijenom tehnologijom i s razvijenim snažnim položajem u marketinškim kanalima. ${ }^{3}$

Ponašanje potrošača vrlo je interesantno područje izučavanja budući da su svi ljudi, osim mnogobrojnih uloga koje imaju, u pojedinim fazama života i potrošači od svog rođenja. Stoga ljudi u ulozi potrošača, iz vlastitog iskustva, mogu izvesti niz zaključaka i samim time bolje razumjeti koncept i teorije ponašanja potrošača. Detaljno proučavanje ponašanja potrošača vrlo je kompleksno budući da brojne varijable interaktivno reagiraju i utječu jedna na drugu i konačno na ponašanje potrošača.Modeli ponašanja potrošača su pretpostavljani skup varijabli i njihovo međusobno djelovanje u procesu donošenja kupovne odluke. ${ }^{4}$

Ponašanje je potrošača pod utjecajem brojnih čimbenika koji su međusobno povezani, a mogu se svrstati u tri skupine: osobni čimbenici, društveni čimbenici, psihološki procesi. ${ }^{5}$ Danas, marketing eksperti govore da je ponašanje potrošača proces, a ne samo interakcija koja se događa u trenutku kada potrošač kupuje proizvod i zbog toga je danas ponašanje potrošača postalo područje interesa za brojne društvene znanosti, što je rezultat kompleksnosti samog procesa ponašanja potrošača, ali još važnije jer obuhvaća važnu ulogu u našim ekonomskim, kulturnim, ali i psihološkim aspektima života. Tome pomaže i činjenica da je sam proces potrošnje važna stavka u našem svakodnevnom životu, u obavljanju svakodnevnih organizacijskih aktivnosti pa čak i stvaranju naše ličnosti.

\section{Stanje trgovačkih lanaca u Mostaru}

U razvijenim gradovima trgovački lanci su sveprisutni i shodno tome između njih postoji velika konkurencija. Konkurentske prednosti pojedinih se ogledaju u značajkama poput geografskog položaja maloprodaje, širine asortimana, cijeni proizvoda, kvaliteti proizvoda odnosno usluga, opremljenosti maloprodaje, ljubaznosti i profesionalnosti osoblja, brzine rada na blagajni i brojnih drugih koji mogu imati presudnu ulogu u odlučivanju kupaca pri odabiru trgovačkog lanca u kojem će obavljati svoju kupnju.

${ }^{3}$ Knego, N., Knežević, B., Renko, S., Promjene u trgovini na malo u Hrvatskoj, Zagreb, 2012., str. 4.

${ }^{4}$ Božić, K., Istraživanje preferencija potrošača u odabiru trgovačkih lanaca u Mostaru, Diplomski rad, Ekonomski fakultet Sveučilišta u Mostaru, Mostar, 2016., str. 26.

${ }_{5}^{5}$ Previšić, J., Ozretić Došen, Đ. - redaktori, Marketing, Adverta, Zagreb, 2007., str. 113. 
Što je to što čini jedan trgovački lanac popularnijim od drugog?

Odgovori na ovo pitanje su različiti. Naravno, pravi odgovor se vjerojatno razlikuje od grada do grada pa je tako cilj ovog rada utvrditi koji su to trgovački lanci koje građani grada Mostara preferiraju i pokušati dobiti jasniju sliku koji se zapravo razlozi kriju iza njihovih preferencija.

Određena znanstvena istraživanja poput istraživanja iz 2015. godine koje je provedeno na uzorku potrošača iz SAD-a pokazuje da najveći utjecaj ima dobivena vrijednost za novac, zatim lokacija, a potom dostupnost proizvoda koje koristi potrošač. ${ }^{6}$

\section{Slika 1 .}

\section{VAŽNOST POJEDINIH ČIMBENIKA NA ODABIR TRGOVAČKOG LANCA ZA AMERIČKE POTROŠAČE IZ 2015. GODINE}

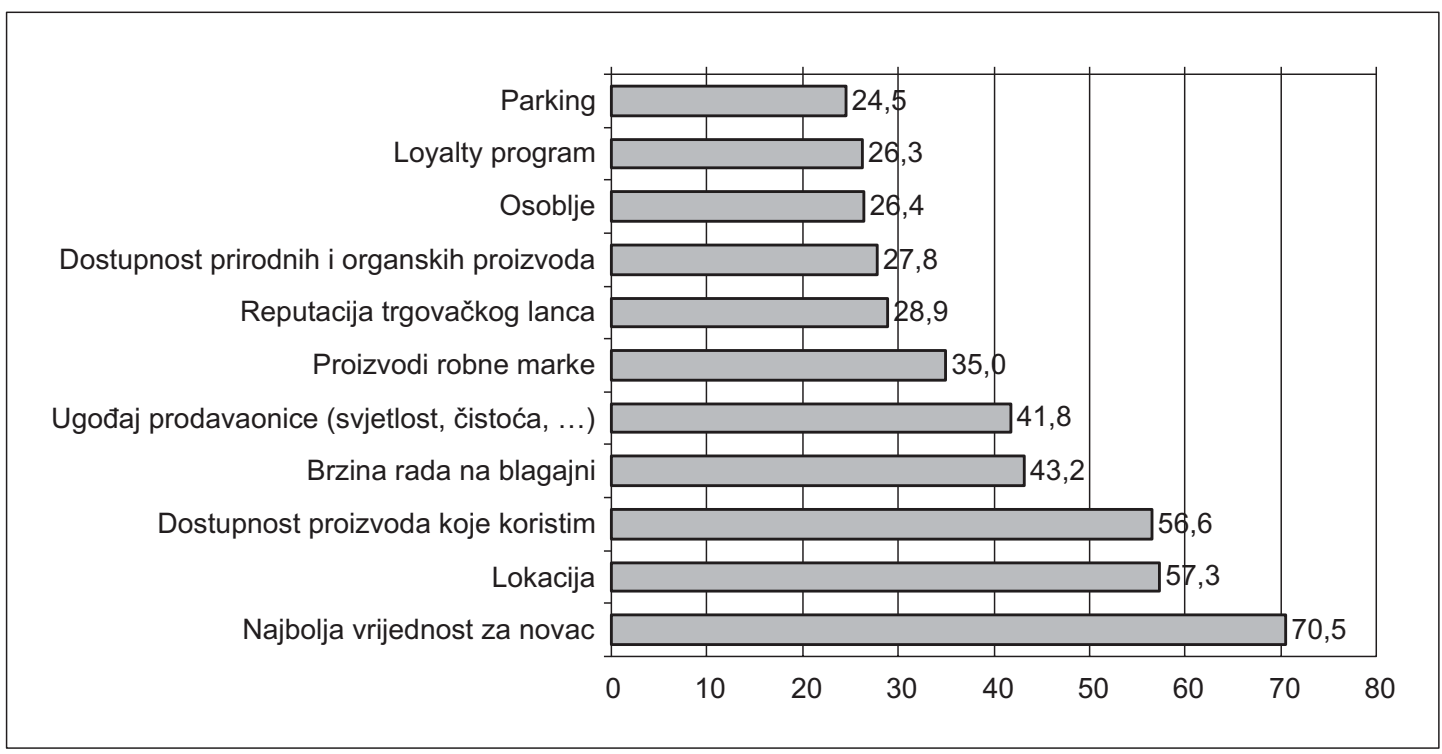

Izvor: https://www.statista.com/statistics/493800/factors-considered-by-us-consumers-in-choosingstores-for-grocery-shopping/

Drugi pak, tvrde drukčije. Prema nama „,bližem“ istraživanju kojeg je pripremila Martina Sošak Susović 2016. godine na primjeru rješenja anketnog upitnika koji je proveden u Splitu rezultati su sljedeći.

${ }^{6}$ Božić, K., op. cit., str. 52. - 53. i https://www.statista.com/statistics/493800/factors-considered-by-us-consumers-in-choosing-stores-for-grocery-shopping/ 
Slika 2.

\section{REZULTATI ANKETNOG UPITNIKA U SPLITU}

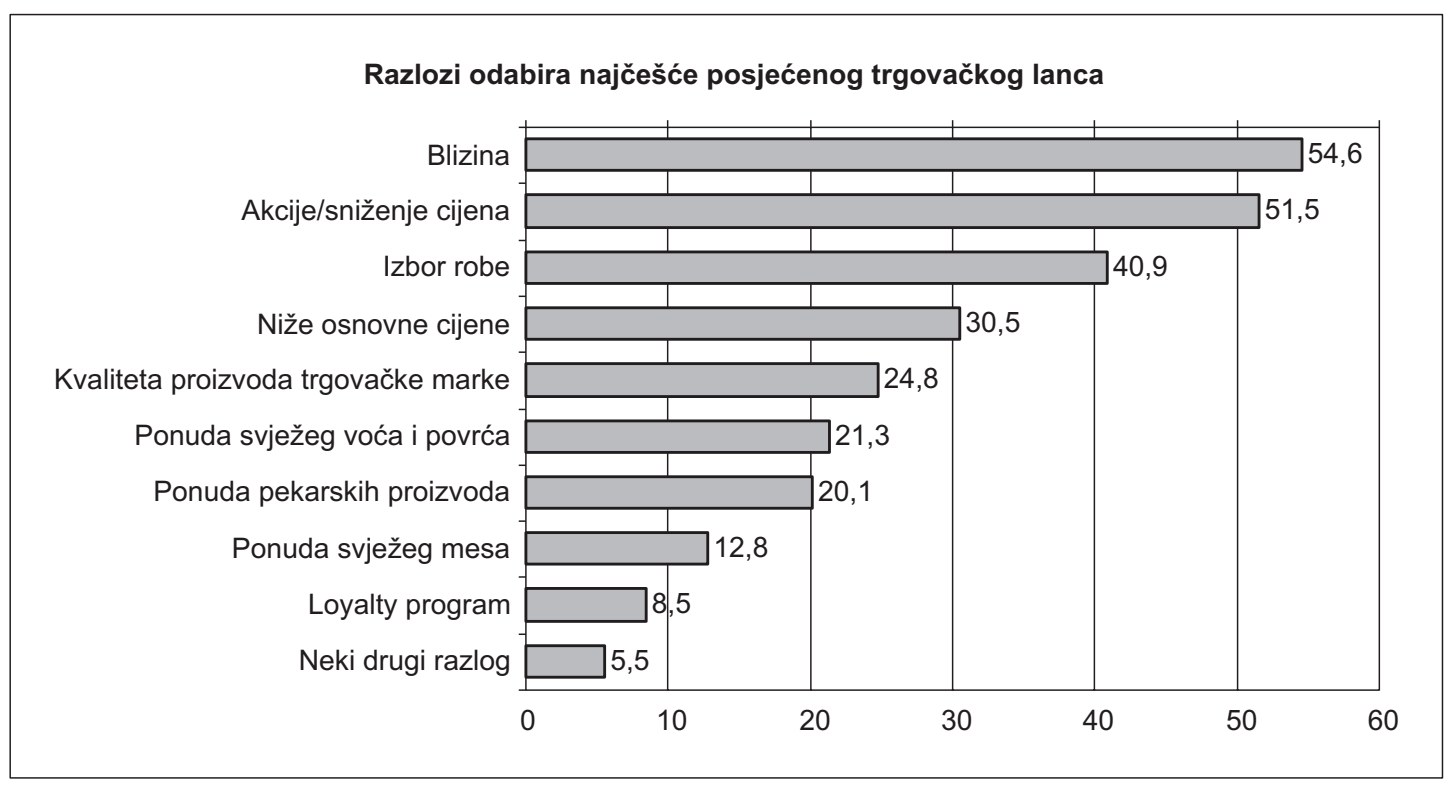

Izvor: https://progressive.com.hr/demo/6813-glavni-razlozi-posjeta-trgovinama-blizina-i-akcije.html

Na primjeru ovog istraživanja vidimo da kupci najviše preferiraju trgovački lanac koji im je geografski najbliže, a kao drugi najvažniji razlog kupovine u određenom trgovačkom lancu navode akcije, odnosno ponudu proizvoda po sniženim cijenama, dok se kvaliteta proizvoda nalazi tek na petom mjestu liste preferencija potrošača grada Splita. ${ }^{7}$

Grad Mostar je kulturno, sveučilišno, prometno, turističko, ali i gospodarsko središte Hercegovine. ${ }^{8}$ Danas Mostar svaki danom dobija na sadržaju i vraća svoj prijeratni izgled. Ne zapostavlja se niti jedan segment životnih potreba, ali se prio-

${ }^{7}$ Božić, K., op. cit., str. 61. - 62. i https://progressive.com.hr/demo/6813-glavni-razlozi-posjeta-trgovinama-blizina-i-akcije.html

${ }^{8}$ Nakon Drugog svjetskog rata Mostar se ubrzano razvijao te se u ekonomskoj oblasti javljaju respektabilni gospodarski kapaciteti kakvi su bili Soko, Aluminij, Hepok, Tekstilni kombinat, Tvornica duhana i drugi. Nažalost, slijedom ratnih događaja u vremenuskom periodu 1992.-1996. godine Mostar doživljava strahovita razaranja i devastaciju što je utjecalo na, između ostalog, cjelokupnu gospodarsku sliku grada. Zbog toga je Europska Unija uspostavila vlastitu upravu u gradu ulažući velika financijska sredstva koja su gradu uvelike pomogla u rješavanju problema u vidu obnove infrastrukture, popravki kuća i zgrada, te obnove zdravstvenih kao i obrazovnih objekata. Jedan dio sredstava utrošen je i na pokretanje gospodarskih aktivnosti i poticanje privatnog poduzetništva. 
ritetno nastoji poticati i stvarati povoljniji ambijent za razvoj gospodarstva. ${ }^{9}$ Prema popisu stanovništva iz 2013. godine Općina Mostar broji 105977 stanovnika ${ }^{10}$, dok sam grad ima 65286 stanovnika. Iako ga ova statistika svrstava u 6. najveći grad po broju stanovnika, Mostar je s aspekta turizma i posjećenosti drugi najpopularniji grad u Bosni i Hercegovini, a ispred njega se nalazi samo Sarajevo. Sve to rezultiralo je relativno velikim brojem trgovačkih lanaca u gradu Mostaru od kojih ćemo izdvojiti 6, a to su Konzum, Bingo, Mercator, Namex, Robot i Mabo.

Konzum $^{11}$ je najveći hrvatski maloprodajni trgovački lanac i nalazi se u većinskom vlasništvu hrvatske tvrtke Agrokor. Svoju prvu samouslugu Konzum otvara 1957. godine u Zagrebu, a na bosanskohercegovačko tržište se širi od 2004. godine otvaranjem prvog Velpro centra u Sarajevu. Prva Konzumova trgovina u Mostaru pojavljuje se već 2007. godine, dok se danas u Mostaru nalazi 17 Konzum prodavaonica. Konzum se želi istaknuti po širokom asortimanu, dugogodišnjoj tradiciji i kvaliteti.

Bingo $^{12}$ je najveći bosanskohercegovački maloprodajni lanac koji postoji od 1993. godine sa sjedištem u Tuzli. Bingo Tuzla d.o.o svoju prvu trgovinu u Mostaru otvara 2011. godine što se ispostavilo odličnim poslovnim pothvatom budući da nije mnogo trebalo da ovaj trgovački lanac postane ponajbolji u očima građana grada Mostara. Bingo ističe društvenu odgovornost, promovira domaću proizvodnju i nudi kvalitetne proizvode po povoljnim cijenama za bosanskohercegovačko stanovnišstvo.

Mercator je najveći slovenski trgovački lanac koji se, kao i Konzum,nalazi u vlasništvu hrvatske tvrtke Agrokor. Iako u Mostaru ima samo 3 svoje trgovine smatra se ponajboljim trgovačkim lancem zbog sjajnog geografskog položaja i širokog asortimana proizvoda. Mercator teži postavljanju novih trendova s ciljem kvalitetnog življenja i zadovoljavanja velikog broja kupaca te u svom asortimanu ima velik broj raznovrsnih zdravih bioloških proizvoda. Njihov slogan je „,bio jednom BIO uvijek“. ${ }^{13}$

Namex je trgovački lanac koji djeluje na području Hercegovine čija je osnovna djelatnost trgovina na malo u nespecijaliziranim prodavnicama. Prvu poslovnicu Namex je otvorio 18.09.2007. u općini Široki Brijeg, a danas posluje u 28 objekata diljem Bosne i Hercegovine s kontinuiranim povećanjem poslovnica i zaposlenih. ${ }^{14}$

\footnotetext{
${ }^{9}$ http://www.mostar.ba/o-gradu-opcenito.html

${ }^{10} \mathrm{https} / / / \mathrm{www} . v e c e r n j i . h r / v i j e s t i / c e k a l o-s e-25$-godine-na-objavu-rezultata-popisastanovnistva-u-bih-ovo-su-prvi-sluzbeni-podaci-nakon-25-godina-1095916

${ }^{11} \mathrm{https} / / /$ www.konzum.hr/O-Konzumu/O-nama/Povijest-razvoja

${ }^{12}$ https://www.bingotuzla.ba/category/bingo/o-nama/

${ }^{13} \mathrm{https} / / /$ www.mercator.ba/bio-jednom-bio-uvijek/biojednombiouvijek/

${ }^{14}$ http://nameks.com/o-nama/
} 
Robot je bosanskohercegovačka kompanija osnovana 1995. godine čija je osnovna djelatnost veleprodaja i maloprodaja tehničkim robama, robom široke potrošnje i prehrambenim proizvodima, shopping centri kao i obavljanje uslužnih djelatnosti. ${ }^{15}$ Teže ka tomu da budu prvi izbor kupcima u Bosni i Hercegovini sa svojom kvalitetnom ponudom proizvoda i usluga po prihvatljivim cijenama za bosanskohercegovačkom stanovništvo.

Mabo je bosanskohercegovačka tvrtka osnovana 13.09.2014. u Biogracima gdje je otvoren i prvi supermarket koji je bio specifičan zbog širokog asortimana proizvoda, davanja prednosti domaćim proizvodima i izuzetno povoljnim cijenama. Trenutno broji 10 supermarketa na području Bosne i Hercegovine te ga s pravom možemo nazvati jednim od najjačih trgovačkih lanaca u regiji. ${ }^{16}$

\section{Istraživanje preferencija potrošača pri odabiru trgovačkih lanaca na području grada Mostara}

U ovom dijelu rada smo dali odgovor na pitanje: Što je to što čini jedan trgovački lanac popularnijim od drugog? Odgovori na ovo pitanje su različiti, a odgovor se razlikuje od grada do grada. Zbog toga je cilj ovog rada bio utvrditi koji su to trgovački lanci koje građani grada Mostara preferiraju i pokušati dobiti jasniju sliku koji se razlozi kriju iza njihovih preferencija.

Stoga je fokus ovog rada je na istraživanju anketnim upitnikom koje je provedeno među građanima grada Mostara. Anketiranje je vršeno licem u lice, ali i putem interneta odnosno aplikacije „Google obrasci“. „Google obrasci“ je web stranica i aplikacija koja omogućava izravno online prikupljanje podataka putem anketnog upitnika ili kviza te obradu istih. ${ }^{17}$

15 https://www.robot.ba/o-nama/o-nama

16 https://www.mabo-supermarket.com/o-nama

17 https://en.wikipedia.org/wiki/Google_Forms; korištenje aplikacije i web stranice „Google obrasci“" je besplatno, jednostavno, a sve što trebate imati je Google račun koji vjerojatno već koristite da bi ste pristupili G-mail-u, Youtube-u ili Google Drive-u. 


\subsection{Hipoteza istraživanja}

Znanstvenu hipotezu ${ }^{18}$ mora biti moguće provjeriti i općenito se temelji na prethodnim opažanjima ili proširenjima znanstvenih teorija. U radu će se provjeriti, odnosno za potrebe ovog istraživanja postaviti dvije hipoteze. ${ }^{19}$

Hipoteza 1. Cijena je čimbenik koji u najvećoj mjeri utječe na kupčeve preferencije u odabiru trgovačkog lanca na području grada Mostara

Hipoteza 2. Konzum je najpopularniji trgovački lanac u Mostaru

\subsection{Predmet i ciljevi istraživanja}

Cilj svakog istraživanja je usko povezan sa predmetom istraživanja. Predmet istraživanja ovog rada su preferencije potrošača u odabiru trgovačkih lanaca, a cilj je utvrditi koji su ključni čimbenici koji utječu na odluke potrošača. Koristeći se odgovorima iz anketnih upitnika možemo procijeniti i brojne druge elemente kao što su čimbenici koji najmanje utječu na potrošačko odlučivanje, a možemo također vidjeti korelaciju između preferencija potrošača i podrijetla trgovačkog lanca odnosno da li je potrošačima bitno, i koliko, da je trgovački lanac domaći, ili više vjeruju stranim lancima ili su pak ravnodušni po ovom pitanju, koliko je bitno da im je trgovački lanac blizu mjesta stanovanja, koliku ulogu ima cijena proizvoda kao i danas popularizirana kartica lojalnosti i slično. Naravno, budući da se postavljena hipoteza 1. odnosi na cijenu kao čimbenik preferencija potrošača grada Mostara glavni fokus je na utjecaj cijene te su stoga ostale varijable koje utječu na proces donošenja odluka zapravo podređene cijeni, odnosno služe za usporedbu s njom. Dakle, glavni cilj rada je utvrditi preferencije potrošača u odabiru trgovačkih lanaca na području grada Mostara te zaključiti koliku ulogu ima cijena u tom odabiru.

${ }^{18}$ Hipoteza je predloženo objašnjenje fenomena ili razumna pretpostavka koja predlaže moguću korelaciju između više fenomena.

${ }^{19}$ Sama riječ hipoteza se izvodi iz grčke riječi hypotithenai što zapravi znači „staviti ispod“ ili „pretpostaviti“. 


\subsection{Metode istraživanja i izvori podataka}

Kao mjerni instrument za potrebe istraživanja kreiran je anketni upitnik ${ }^{20}$ koji se sastoji od 28 pitanja. Prva 4 pitanja odnose se na socioekonomske i demografske varijable, dok je drugi dio upitnika strukturiran prema Likertovoj ljestvici i čine ga pitanja vezana za predmet istraživanja tj. 24 pitanja. Likertova skala je vrsta skale stavova koja se sastoji od niza tvrdnji posvećenih različitim aspektima nekog stava. ${ }^{21}$ Skala se sastoji od tvrdnji ,uopće se ne slažem”, ,,ne slažem se”, ,nemam mišljenje”, ,slažem se" i ,potpuno se slažem”.Primjer anketnog upitnika se nalazi u Prilogu 1. Istraživanje je provedeno od 25. rujna do 25. listopada 2018. godine na području grada Mostara (Bosna i Hercegovina). ${ }^{22}$ Uzorak istraživanja pripada grupi namjernih, odnosno neproporcionalnih kvotnih uzoraka ${ }^{23}$ uz kontrolnu varijablu spol i dob ispitanika. Za potrebe istraživanja ispitali smo 215 ispitanika s područja grada Mostara od čega je 109 (50.7\%) muškaraca i 106 (49.3\%) žena. Ispitanici su učenici, studenti, zaposleni, nezaposleni ili umirovljenici. Nakon provedenog istraživanja dobili su se rezultati istraživanja pomoću kojih će se odrediti najpopularniji trgovački lanci na području grada Mostara te kriteriji prema kojima se stanovnici grada Mostara opredjeljuju za njihove najdraže trgovačke lance.

\subsection{Analiza odgovora ukupnog uzorka}

Dobna struktura ispitanika varirala je od 18 do 68 i više godina. Sukladno velikom rasponu godina ispitanici su svrstani u sljedeće dobne skupine: 18-27 godina, 52\% ispitanika, 28-37 godina, $19 \%$ ispitanika, 38-47 godina, $11 \%$ ispitanika, $48-57,8 \%$ ispitanika $58-67,7 \%$ ispitanika te 68 i više, $3 \%$ ispitanika. Što se tiče načina provođenja anketnih upitnika $75 \%$ ispitanika ispunilo je anketu putem interneta, dok je preostalih $25 \%$ anketu ispunilo „oči u oči“ što objašnjava i dominantan broj mlađih ispitanika. ${ }^{24}$

${ }^{20}$ Za ovaj anketni upitnik je provedeno pilot istraživanje, nakon kojeg su otklonjene uočene pogreške u formulaciji pitanja. Prvo istraživanje s ovim upitnikom je izvršeno u početkom rujna 2018. godine, ovo je drugo istraživanje na istom upitniku. Mislimo da bi bilo dobro provesti anketiranje u Sarajevu, Tuzli i Banja Luci.

${ }^{21}$ https://sh.wikipedia.org/wiki/Likertova_skala (05.11.2015.)

${ }^{22}$ Istraživanjem je bila namjera ispitati 250 ispitanika, ali smo zbog vremenskog ograničenja ispitali 215 ispitanika.

${ }^{23}$ Uzorak istraživanja pripada grupi namjernih, odnosno neproporcionalnih kvotnih uzoraka uz kontrolnu varijablu spol i dob ispitanika.

${ }^{24}$ Istaživanjem je ispitano 215 ispitanika, od toga 150 putem interneta tj. online, a 65 metodom licem u lice. 
S obzirom da većina ispitanika pripada mlađim dobnim skupinama za očekivati je da i stupanj obrazovanja bude visok. Iako tako, najveći broj ispitanika je s diplomom srednje škole (57.2\%), a potom slijede ispitanici s višom stručnom spremom (15.8\%). $13.5 \%$ ispitanika je završilo magisterij, a nakon njih slijede ispitanici s diplomom više škole (10.2\%). Samo $1.4 \%$ ispitanika je sa osnovnom školom. Logično je pretpostaviti da relevantan broj ispitanika u dobi između 18 i 27 godina zapravo trenutno studira.

Što se tiče mjesečnih primanja može se zaključiti da najveći broj ispitanika spada u državni prosjek što je i očekivana statistika. Čak $33 \%$ posto ispitanika spada u onu grupu u kojoj su mjesečna primanja između 701KM i 1050KM. Najmanji broj ispitanika spada u grupu u kojoj su mjesečna primanja između 351KM i $700 \mathrm{KM}$, dok relativno visok broj ispitanika (16.7\%) ima mjesečna primanja manja od 350KM.

Na pitanje „Koji Vam trgovački lanac prvi pada na pamet?“ čak je 140 ispitanika (65\%) odgovorila sa Konzum, dok je 66 njih (31\%) odgovorilo s Bingo. Iako je relativno nizak broj ispitanika odgovorilo da je Mercator trgovački lanac koji im prvi pada na pamet možemo ga svrstati među najpoznatije trgovačke lance u Mostaru zbog same konstrukcije ovog pitanja.Naravno zbog raznovrsnosti grada Mostara po pitanju etničke pripadnosti možemo donijeti određene zaključke na temu korelacije nacionalne pripadnosti i privrženosti određenom trgovačkom lan$\mathrm{cu}$, međutim ovo istraživanje koncentrira se na sveukupni pregled te je pri odabiru ispitanika dana pažnja stanovnicima svih nacionalnih pripadnosti ne ulazeći dublje u navedenu problematiku na temelju same ankete.

Na slici 3. navedeno je 6 trgovačkih lanaca koji se nalaze na području grada Mostara i posjećenost istih na temelju rezultata anketnog upitnika. Konzum je vidljivo najposjećeniji trgovački lanac u Mostaru i 72 ispitanika odgovorilo je da ga posjećuje svaki dan dok samo 8 ispitanika nikada nije posjetilo navedeni trgovački lanac. Nakon njega slijedi Bingo kojeg svaki dan posjećuje 23 ispitanika, a zanimljivo je da je veći broj ispitanika odgovorilo da nekoliko puta mjesečno posjećuje Bingo. Kao i u slučaju Konzuma jako nizak postotak ispitanika (8.2\%) nikada nije posjetilo Bingo. Iz istog grafa možemo zaključiti da je Mabo trgovački lanac koji je najmanje popularan među stanovnicima grada Mostar te čak 117 ispitanika nikada nije posjetilo ovaj supermarket, a samo 2 ispitanika ga posjećuju svaki dan. 
Slika 3.

POSJEĆENOST TRGOVAČKIH LANACA U MOSTARU

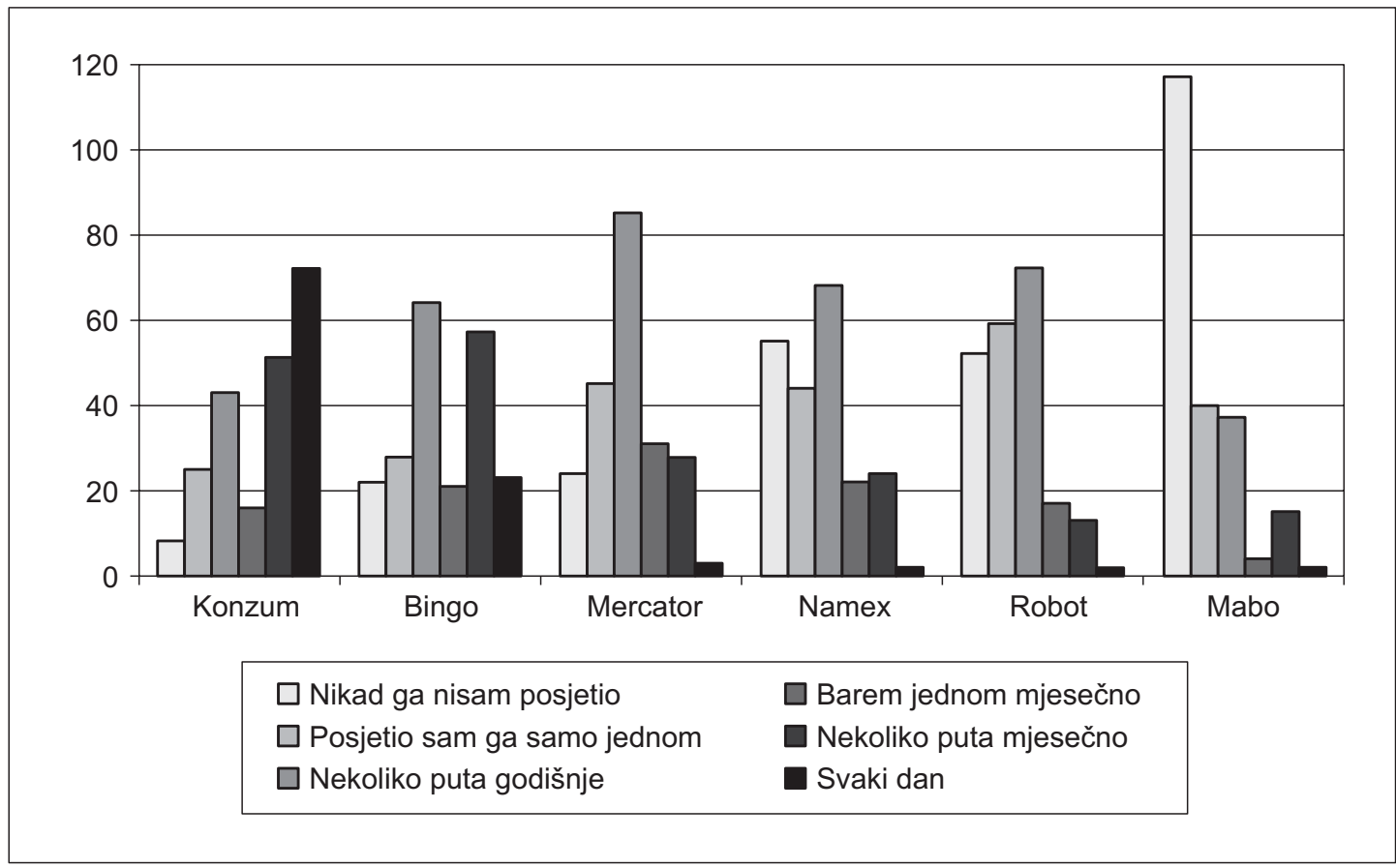

Izvor: Empirijsko istraživanje. 
Slika 4.

NAJČEŠĆI RAZLOZI POSJEĆENOSTI TRGOVAČKIH LANACA

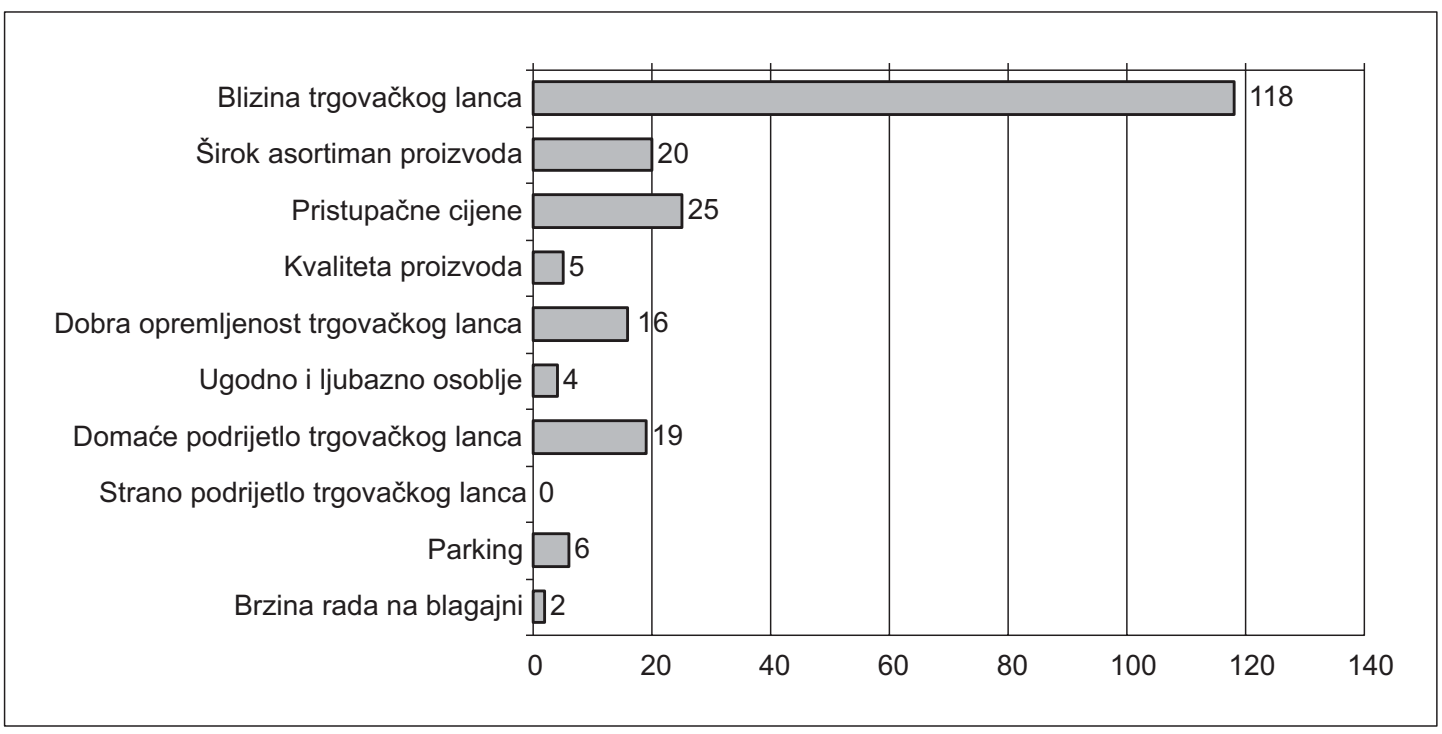

Izvor: Empirijsko istraživanje.

Pomalo i iznenađujuće dominantan odgovor na pitanje glavnog razloga najčešće posjećenosti određenog trgovačkog lanca je blizina trgovačkog lanca, nakon čega tek slijedi cijena kao motivirajući čimbenik, a potom širina asortimana proizvoda. Također, zanimljivo je da nitko od ispitanika nije naveo strano podrijetlo trgovačkog lanca kao razlog posjećenosti. Naravno važno je napomenuti da zbog dominacije triju velikih trgovačkih lanaca (Konzum, Bingo i Mercator), što imidžom i što rasprostranjenošću, stanovnici grada Mostara uglavnom žive u blizini jednog od navedenih te se može zaključiti da sama činjenica što u relativnoj blizini imaju trgovački lanac sa širokim asortimanom i pristupačnim cijenama utječe na stavove o odgovoru na ovo pitanje. 
Slika 5 .

\section{SEKUNDARNI RAZLOZI POSJEĆENOSTI TRGOVAČKIH LANACA}

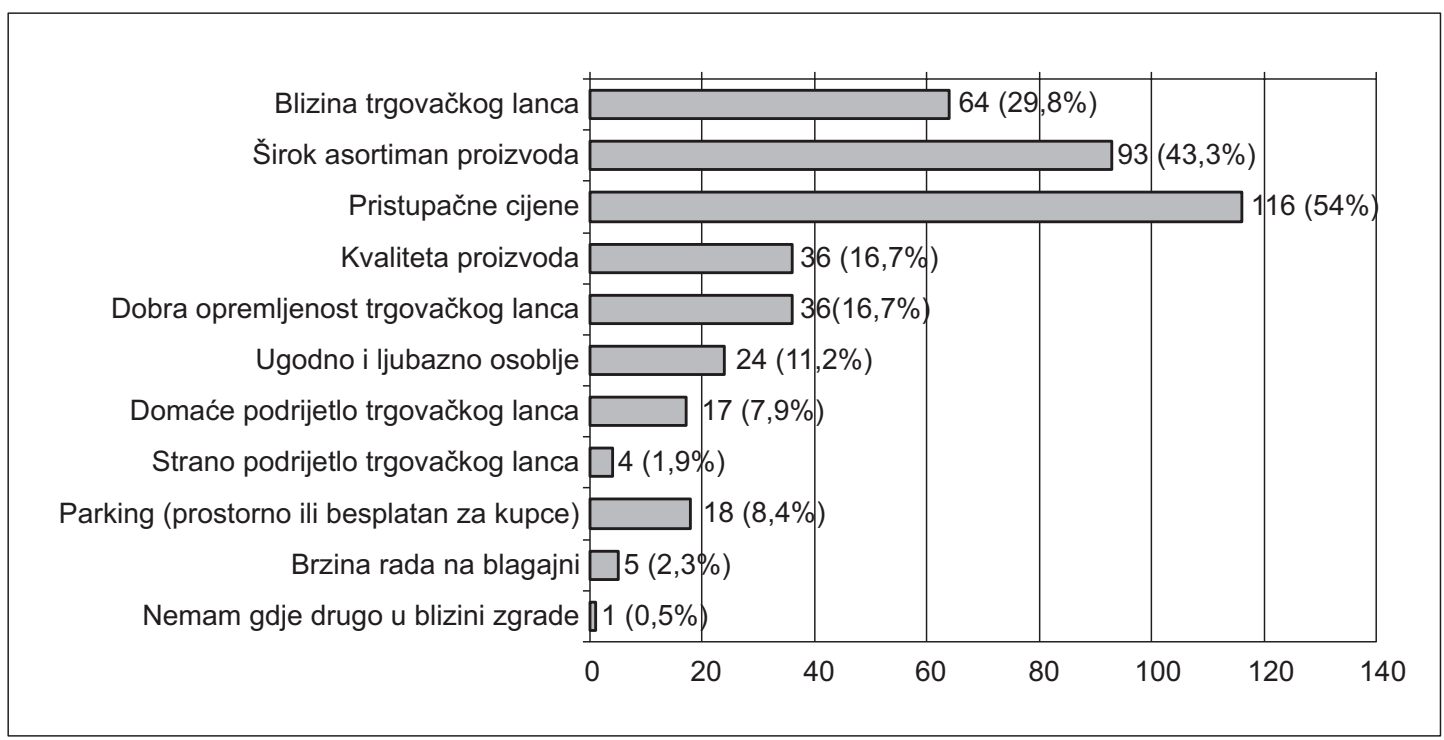

Izvor: Empirijsko istraživanje.

Na slici 5. možemo vidjeti i mišljenja ispitanika na pitanje koja su druga dva razloga njihova posjećivanja određenog trgovačkog lanca gdje je 54\% ispitanika odgovorilo da je cijena, a $43.3 \%$ ispitanika je odabralo širinu asortimana.

Nadalje, prema rezultatima istraživanja možemo zaključiti da, danas popularizirane, kartice lojalnosti nisu u većoj mjeri značajne za ispitanike u njihovom odabiru trgovačkog lanca u kojem će obavljati svoju kupovinu, odnosno samo $15.5 \%$ ispitanika odgovorilo je da kupuje u određenom trgovačkom lancu zato što posjeduje njegovu karticu lojalnosti.

Preostala pitanja u anketnom upitniku odnosila su se na navedene varijable pojedinačno kako bi se proučila konzistentnost odgovora, ali i dobila cjelokupna slika o svakom čimbeniku i njegovom značaju za potrošače grada Mostara. Odgovori su bili konzistentni sa slikom 4. s tim da su određeni čimbenici poput širine asortimane proizvoda i cijene proizvoda značajno dobili na popularnosti, odnosno čak 94\% ispitanika dalo je ocjenu 4 ili 5 za tvrdnju „Volim kada mogu sve kupiti na jednom mjestu jer je ponuda raznovrsna“.

S obzirom na navedeno, može se zaključiti da se Hipoteza 1. u potpunosti odbacuje, odnosno cijena nije najvažniji čimbenik za potrošače pri odabiru trgovačkih lanaca na području grada Mostara, a da se Hipoteza 2. može po- 
tvrditi, odnosno Konzum je najpopularniji trgovački lanac na području grada Mostara. $^{25}$

\section{Zaključak}

Mostar je jedan od najvećih gradova u Bosni i Hercegovini i prostorno i po broju stanovnika, ali i po posjećenosti turista. Kao takav, popularno je odredište za razne regionalne, nacionalne i internacionalne trgovačke lance te u gradu Mostaru danas imamo relativno velik broj trgovačkih lanaca koji si međusobno konkuriraju.

Na temelju rezultata anketnog upitnika u kojem je sudjelovalo 215 ispitanika od kojih je 109 (50.7\%) muškaraca i 106 (49.3\%) žena možemo izdvojiti neke opservacije koje se tiču prvenstveno popularnosti trgovačkih lanaca i razloga njihove popularnosti u Mostaru. Pokušavajući napraviti distinkciju između subjektivnog i objektivnog zaključivanja o privrženosti potrošača određenom trgovačkom lanca postavljena su slična, ali ipak različita pitanja u kojima se ogleda donekle značajna razlika u pogledu trgovačkih lanaca od strane ispitanika tako da vidimo da je trgovački lanac Konzum manje popularan kada je pitanje objektivnije postavljeno, dok su trgovački lanci poput Binga i Mercatora dobili na popularnosti kada je u pitanju objektivnije postavljeno pitanje. Međutim, prema svim postavljenim pitanjima koje se tiču popularnosti određenih trgovačkih lanaca u Mostaru očituje se kontinuitet u rezultatima poput tog da se Konzum nalazi na prvom, Bingo na drugom, a Mercator na trećem mjestu. Slična situacija vidljiva je i u odabiru glavnih kriterija pri opredjeljenju za određeni trgovački lanac. Kao glavni razlog odabira trgovačkog lanca ispitanici su odabrali njegovu blizinu, nakon čega su odabrali širinu asortimana proizvoda, a tek na trećem mjestu je cijena proizvoda. Preostali kriteriji poput kvalitete proizvoda, osoblja, podrijetla trgovačkog lanca dobili su nešto manju popularnost i statistički su otprilike jednako bitni.

Iz navedenog možemo zaključiti da se Hipoteza 1., odnosno pretpostavka da je cijena ključni čimbenik u odabiru trgovačkih lanaca na području grada Mostara, u potpunosti odbacuje. S druge strane, rezultati istraživanja se slažu s pretpostavkom da je Konzum najpopularniji trgovački lanac na području grada Mostara te se Hipoteza 2. može potvrditi.

Značaj ili znanstveni doprinos ovog istraživanja je dvojak, ovaj rad može koristiti marketarima i menadžerima u poduzećima i trgovačkim centrima koji

${ }^{25} \mathrm{U}$ ovom članku su prikazani najzanimljiviji rezultati. Više o istraživanju i dokazivanju hipoteza uBožić, K., op. cit., str. 61. - 83. 
posluju na tržištima gdje je sve veća konkurencija kako bi svoje potrošače potakli da više kupuju te time povećali prodaju i konkurentnost što je podjednako važno i za znanstvenike (istraživanje tržišta, prodaja, ponašanje potrošača) s aspekta boljeg razumijevanja preferencija i čimbenika koji utječu na izbor trgovačkog lanca.

Provedeno istraživanje i analiza imaju i određenih nedostataka i ograničenja. Ono je kao i većina drugih marketinških istraživanja provedeno u određenom trenutku te bi ponovljeno ili kontinuirano istraživanje, tijekom duljeg vremenskog razdoblja, doprinjelo većoj pouzdanosti rezultata. Isto tako, ovo istraživanje je provedeno na području grada Mostara pa time rezultati istraživanja ne moraju vrijediti za druge gradove. Mislimo da bi bilo dobro provesti anketiranje u Sarajevu, Tuzli i Banja Luci,a također i u većim gradovima u drugim zemljama u regiji. Bilo bi zanimljivo ove rezultate usporediti sa razvijenim i manje razvijenim zemljama u regiji. Zatim, korišten uzorak je bio relativno mal, i u drugim istraživanjima bilo bi zanimljivo ispitati veći broj ispitanika.

\section{Literatura:}

Anić I.-D., Rajh E., An analysis of demographic and benefit sought effects on purchasing outcomes in the Croatian footwear market, Ekonomski pregled, Vol. 59, No. 5-6., lipanj 2008.

Anić, I. - D., Piri Rajh, S., Rajh, E., Razlike u stilovima odlučivanja potrošača s obzirom na spol ispitanika u Hrvatskoj, Tržište, vol. 22, No. 1., Zagreb, 2010.

Anić I.- D., Jelenc L., Nevija, Š., Istraživanje demografskih obilježja i ponašanja kupaca ekoloških prehrambenih proizvoda u Karlovačkoj županiji, Ekonomska misao i praksa, No. 2, 2015.

Babić-Hodović, V., Domazet, A., Kurtović, E. - redaktori, Osnovi marketinga - 4. Izmijenjeno i dopunjeno izdanje, Ekonomski fakultet u Sarajevu, Sarajevo, 2012.

Babić-Hodović, V., Arslanagić, M., Mehić, E., Importance of Internal Marketing for Service Companies Corporate Reputation and Customer Satisfaction, Journal of Business Administration Research, Vol. 2(1), 2013., 49-57.

Božić, K., Istraživanje preferencija potrošača u odabiru trgovačkih lanaca u Mostaru, Diplomski rad, Ekonomski fakultet Sveučilišta u Mostaru, Mostar, 2016.

Brkić, N., Čorbo, M., Berberović, D., Ethnocentrism and Animosity in Consumer Behaviour in Bosnia and Herzegovina and Implications for Companies", Economic Review: Journal of Economics and Business, Faculty of Economics, University of Tuzla, Vol. 9, Issue 1, June 2011, pp. 45-61. (ISSN 1512-8962) 
Čičić, M., Husić, M. Kukić, S., Ponašanje potrošača, Ekonomski fakultet, Sveučilište u Mostaru, SUTON d.o.o., Široki Brijeg, 2009.

Čutura, M., Poslovna etika i društvena odgovornost u području marketinga, Ekonomski fakultet Sveučilišta u Mostaru, Mostar, 2016.

Dunković, D., Poslovno upravljanje u trgovini, Ekonomski fakultet u Zagrebu, Zagreb, 2015.

Dibb, S., Simkin, L., Pride, W. M., Ferrell, O. C., Marketing, Mate, Zagreb, 1995.

Engel, F. J., Blackwell, D. R., Miniard, W. P., Consumer Behavior (seventh ed.), The Dryden Press, 1995.

Grupa autora, Marketing, Ekonomski fakultet Sveučilište u Mostaru, Mostar, 2007.

Jurković Majić, O., Istraživanje zadovoljstva učenika kvalitetom usluge srednjoškolskog obrazovanja u Republici Hrvatskoj, Tržište, Vol. 19., No. 2., 2007., str. 231. -240 .

Kemboi, A., Kiprono Biwott, G., Kiptanui Tarus, T., Service quality as a catalyst for customer satisfaction of small and medium sized enterprises (SMEs) in Kitale municipality, Kenya, International Journal of Business and Management Review Vol.2, No.4, 2014., str. 71 - 79.

Kernbach, S., Schutte, N.S., The impact of service provider emotional intelligence on customer satisfaction, Journal of Services Marketing, Vol. 19, No. 7, 2005, str. 438-444.

Kesić, T.; Marketinška komunikacija - propaganda, unapređenje prodaje, Internet, odnosi s javnošću, publicitet, osobna prodaja; Opinio, Zagreb, 2003.

Kesić,T., Ponašanje potrošača, Opinio, Zagreb, 2006.

Knego, N., Knežević, B., Renko, S., Promjene u trgovini na malo u Hrvatskoj, Zagreb, 2012.

Kos, A., Trstenjak, M., Kralj, A., Zadovoljstvo kupaca - kako ga mjeriti?, Stručni rad, Međimursko veleučilište u Čakovcu, Čakovec, 2011.

Kotler, Ph., Keller, K. L., Martinović, M., Upravljanje marketingom - 14. izdanje,Mate, Zagreb, 2014.

Marijanović, Z., Statistika, Ekonomski fakultet Sveučilišta u Mostaru, Mostar, 2009.

Marušić, M, Vranešević, T, Istraživanje turističkih tržišta, Adeco, Zagreb, 2001.

Marušić, M,, Prebežac, D, Istraživanje tržišta, 5. izd., Adeco, Zagreb, 2004.

Mihić, M., Segmentacija kupaca u supermarketima na osnovi njihova zadovoljstva prodajnim osobljem, Ekonomski preglednik, Sveučilište u Splitu, Vol. 57., No. 12, 2006., str. $919-938$. 
Nefat, A., Paus, N., Odrednice zadovoljstva korisnika susretom s uslugom, Tržište, Vol. 20., No. 2., 2008., str. 195. - 210.

Previšić, J., Ozretić Došen, Đ. - redaktori, Marketing, Adverta, Zagreb, 2007.

Sinčić Ćorić, D., Vorkapić, I., Istraživanje povezanosti zadovoljstva asortimanom, lojalnosti i reputacije na poslovnom tržištu, Zbornik Ekonomskog fakulteta u Zagrebu, Zagreb, 2008, str. 339-351,

Slišković, A., Zebić, I., Gregov, Lj., Nikolić, M., Uloga sociodemografskih karakteristika i životnog stila potrošača u određenju sklonosti kupovini, Tržište, Vol. 26., No. 2., 2014., str. 227. - 244.

Soče Kraljević, S., Brekalo, M., Istraživanje psiholoških čimbenika koji utječu na ponašanje potrošača, Međunarodna konferencija o ekonomskim i društvenim studijama 2014 (International Conference on Economic and Social Studies), International Burch University,Sarajevo, 24. i 25. 04. 2014., ISSN: 2303 4564., str. 193.

Soče Kraljević, S., Šaravanja, R., Istraživanje utjecaja prodajnog osoblja / usluge na zadovoljstvo korisnika na donošenje odluke o kupnji, Ekonomski fakultet, Sveučilište u Mostaru, Mostar, 2015.

Soče Kraljević, S., Krstanović, Z., Mabić, M., Impact of public relations on the process of purchase decision, Media, culture and public relations,Vol. 7., No. 1.,Hrvatsko komunikološko društvo, Zagreb, ISSN: 1333 - 6371., UDK: 007:002:02., ožujak 2016., str. 79 - 90.

Soče Kraljević, S., Galić, S., Krstanović, Z., Istraživanje utjecaja demografskih čimbenika na impulzivnu kupovinu, Ekonomski fakultet, Sveučilište u Mostaru, Mostar, 2016.

Soče Kraljević, S., Proces istraživanja tržišta, Ekonomski fakultet u Mostaru, Mostar, 2016.

Tipurić, D., Fabac, R., Pološki, N., Konkurentska sposobnost poduzeća, Sinergija, Zagreb, 1999.

Tkalac Verčič, A., Sinčić Ćorić, D., Pološki Vokić, N., Priručnik za metodologiju istraživačkog rada - Kako osmisliti, provesti i opisati znanstveno i stručno istraživanje, Zagreb, M.E.P. d.o.o., 2010.

Tkalac Verčič, A., Sinčić Ćorić, D., The relationship between reputation, employer branding and corporate social responsibility, Public relations review (03638111) 44 (2018), 4; 444-452.

Vranešević, T., Tržišna istraživanja u poslovnom upravljanju, Ekonomski fakultet u Zagrebu, Accent, Zagreb, 2014.

Zikmund, W. G., Babn, J. B., Car, C. J., Griffin, M., Business Research Methods, South - Wester, 9. Izd., 2013. 


\section{Internet izvori:}

www.faktor.ba

www.wikipedia.hr/trgovački_lanac

http://www.mostar.ba/o-gradu-opcenito.html

https://www.vecernji.hr/vijesti/cekalo-se-25-godine-na-objavu-rezultata-popisastanovnistva-u-bih-ovo-su-prvi-sluzbeni-podaci-nakon-25-godina-1095916

https://www.konzum.hr/O-Konzumu/O-nama/Povijest-razvoja

http://www.konzum.co.ba/O-Konzumu/O-nama/Historija-razvoja

https://www.bingotuzla.ba/category/bingo/o-nama/

https://www.mercator.ba/bio-jednom-bio-uvijek/biojednombiouvijek/

http://nameks.com/o-nama/

https://www.robot.ba/o-nama/o-nama

https://www.mabo-supermarket.com/o-nama

https:/www.statista.com/statistics/493800/factors-considered-by-us-consumersin-choosing-stores-for-grocery-shopping/

https://progressive.com.hr/demo/6813-glavni-razlozi-posjeta-trgovinama-blizinai-akcije.html

\section{RESEARCH OF CONSUMER PREFERENCES IN CHOOSING CHAIN STORES}

\section{Summary}

Food market across European Union is dominated by chain stores and recently this trend can also be noticed in Bosnia and Herzegovina. Despite existance of competition laws we are yet to figure out how to control power of big chain stores. According to research of British Competition Comission, any chain store which has more than eight per cent of the share on the food market also has enough power to have negative influence on market competition. Buying habits of consumers are one of the most important factors which can determine the image of chain store, both locally and globally. Undeterred by sovereign nature of modern consumers, marketers can still easily influence consumers' behaviour. Marketers can influence consumers' behaviour by adjusting elements of marketing mix to the counsumers' needs. The success comes if there are needs or those needs are latent while manufacturer induces them product whom consumers need, whether consciously or subconsciously. Consumer behaviour is influenced by several correlated factors: personal, social and psychological. There fore, the aim of this research is to deteremine consumers' preferences in choosing Mostar-based chain stores. This research is based on surveys which took place among 
people of Mostar and through the same survey, alongside consumers' preferences in their choice of chain stores based in Mostar, we'll try to find out key determinants which influence upon those decisions. Through this primary research we can notice that different factors influence different consumers in their choice of chain stores whereas the most important factor seems to be 'close proximity to home'. Significance of this research is double-natured as it can serve to both marketers and managers in companies and chain stores that operate on high competition markets in order to stimulate consumers to buy more and thereby to raise sale and competitiveness. Furthermore, this research is equally important for economists (market research, sale, consumer behaviour) since gathered information enables them to gain better understand of preferences and determining factors in consumers' choice of chain stores. At the end of this paper we pointed out restrictions as well as guidelines for future researches.

Key words: market research, chain store, consumer behaviour, consumer preferences, Mostar 